Men, Women and Madness 


\section{Also by Joan Busfield}

Thinking About Children: Sociology and Fertility in Post-War England (with Michael Paddon)

Managing Madness: Changing Ideas and Practice 


\title{
Men, Women and Madness
}

\author{
Understanding Gender and Mental Disorder
}

JOAN BUSFIELD

Consultant Editor: Jo Campling 
(C) Joan Busfield 1996

Softcover reprint of the hardcover 1st edition 1996 978-0-333-46369-7

All rights reserved. No reproduction, copy or transmission of this publication may be made without written permission.

No paragraph of this publication may be reproduced, copied or transmitted save with written permission or in accordance with the provisions of the Copyright, Designs and Patents Act 1988, or under the terms of any licence permitting limited copying issued by the Copyright Licensing Agency, 90 Tottenham Court Road, London W1P 9HE.

Any person who does any unauthorised act in relation to this publication may be liable to criminal prosecution and civil claims for damages.

First published 1996 by

MACMILLAN PRESS LTD

Houndmills, Basingstoke, Hampshire RG21 6XS

and London

Companies and representatives

throughout the world

ISBN 978-0-333-46370-3 ISBN 978-1-349-24678-6 (eBook)

DOI 10.1007/ 978-1-349-24678-6

A catalogue record for this book is available from the British Library.

Transferred to digital printing 2005 


\section{Contents}

List of Tables and Figures viii

Acknowledgements $\quad$ x

Preface $\quad$ xi

1. Introduction 1

PART I GENDER, GONSTRUCTS AND SERVICES

2. The Gendered Landscape 13

Gender and Diagnosis 14

Gender, Age and Mental Disorder $\quad 22$

Marital Status, Social Class and Ethnicity $\quad 25$

Historical Changes $\quad 28$

$\begin{array}{ll}\text { Conclusion } & 30\end{array}$

3. Gender and Feminist Theorising 31

The Concept of Gender $\quad 32$

Theorising Gender $\quad 38$

The Foundations for a Theory of Gender 48

4. Mentai Disorder, Medicine and the Regulation

of Rationality 51

The Terrain of Mental Disorder $\quad 52$

Theorising Mental Disorder $\quad 60$

The Regulation of Rationality $\quad 69$

5. Measuring Mental Disorder $\quad 76$

$\begin{array}{ll}\text { Patient Statistics } & 77\end{array}$

Community Surveys $\quad 82$

The Case of Depression $\quad 90$

Conclusion $\quad 95$ 
6. Gender and Constructs of Mental Disorder 98

Chesler's Analysis $\quad 99$

Official Constructions 102

Gender, Agency and Rationality 105

Normal Cases 108

Case Identification $\quad 114$

$\begin{array}{ll}\text { Conclusion } & 117\end{array}$

7. The Historical Context 119

Societal Categories of Madness and Mental Disorder $\quad 120$

Institutions for Lunatics $\quad 123$

Outside the Asylum $\quad 129$

Community Care 133

Conclusion 138

PART II GENDER AND THE ORIGINS OF MENTAL DISORDER

8. Biological Origins

Nineteenth-Century Ideas $\quad 146$

Twentieth-Century Ideas 152

$\begin{array}{ll}\text { Conclusion } & 164\end{array}$

9. Feminist Psychologies and Gendered Individuals $\quad 166$

Feminists and the Freudian Heritage 167

The Case of Anorexia Nervosa 175

Conclusion 186

10. Stress and the Gender Division of Labour 188

Stress and Mental Disorder $\quad 189$

The Gender Division of Labour 200

Conclusion $\quad 207$

11. Trauma and Powerlessness: War and Sexual Violence 209

War, Masculinity and Shell-Shock 212

Sexual Violence $\quad 222$

Conclusion $\quad 229$ 
12. Conclusion 230

An Alternative Approach $\quad 232$

Policy Implications 232

$\begin{array}{ll}\text { Notes } & 241\end{array}$

$\begin{array}{ll}\text { Bibliography } & 256\end{array}$

$\begin{array}{ll}\text { Name Index } & 274\end{array}$

$\begin{array}{ll}\text { Subject Index } & 280\end{array}$ 


\section{List of Tables and Figures}

\section{Tables}

2.1 Episodes of Illness in General Practice for Selected

Diagnoses by Gender, England and Wales, 1981-82

2.2 All Admissions to Mental Illness Hospitals and Units, England, 1986

2.3 Patients Consulting General Practitioners for Mental Disorders by Gender, England and Wales, 1981-82

2.4 Residents of Psychiatric Beds, England, 1972-76

2.5 Patients Resident in Mental Illness Hospitals and Units by Sex and Marital Status, England and Wales, 31 December 1971

2.6 Sex Specific Rates of Mental Hospital Admissions in England and Wales by Selected Diagnoses and Country of Birth, 1971

2.7 Admission Rates to Mental Hospitals in England and Wales by Age and Gender, 1884-1957

7.1 Distribution of Lunatics at 1 January 1880 by Type of Institution, Status of Patient and Gender

7.2 Admissions of Lunatics by Gender and Marital Status

7.3 Admissions by Selective Diagnostic Group, percentages, England

10.1 The Holmes-Rahe Social Readjustment Rating Scale 


\section{Figures}

4.1 The Assimilation of Mental Disorder 53

4.2 The Contested Boundaries of Mental Disorder 55

10.1 Causal Model of Depression 


\section{Acknowledgements}

The author and publishers wish to thank the following for permission to use copyright material:

R. Cochrane for Table 6 from The Social Creation of Mental Illness, 1984, Longman, p. 91; The Controller of Her Majesty's Stationery Office for Tables 2, 4, 5, 10 from Crown copyright material; Royal College of General Practice for Tables 1, 3 from Morbidity Statistics from General Practice, 1981-2, 1986, Tables 8, 17; Tavistock Publications for Fig. 3 from G. W. Brown and T. Harris, Social Origins of Depression: A Study of Psychiatric Disorder in Women.

Every effort has been made to trace all the copyright holders but if any have been inadvertently overlooked the publishers will be pleased to make the necessary arrangement at the first opportunity. 


\section{Preface}

The phenomena of mental illness or, to use a less medical term, mental disorder, attract enormous interest both lay and professional. ${ }^{1}$ In lay understandings terms like mental illness and mental disorder frequently generate images of severe disturbance involving hallucinations and delusions - real madness - that often seem threatening, disturbing and dangerous, as well as difficult to comprehend. Equally the terms may conjure up images of people who face severe difficulties in their lives and become depressed or anxious, or resort to drugs or alcohol to deal with their problems. Such images, whether of the difficult and dangerous, or of the disturbed and tormented, conflict with the more detached, scientific language of illness and the formal characteristics of mental disorders provided by psychiatrists.

Yet, this detached, formal language hides a terrain that is highly contested both within psychiatry and between psychiatry and other mental health professions, and beneath the scientific language there is turbulence and controversy. There are contests over the precise boundaries of mental disorder and over what phenomena, if any, properly belong to the category, as well as over the language with which the phenomena should be described. There are also major debates about the identification of particular individuals as mentally disturbed, about the causes of mental disorder, and about the appropriate form of response to those who are deemed disordered. ${ }^{2}$

My aim in this book is not to try to settle all these key areas of debate. Rather it is to explore one controversial area: that concerning the relationship between gender and mental disorder. This will, however, require some examination of other disputed areas, especially that surrounding the category of mental disorder itself. Nonetheless, my overriding objective is to explore the interconnections between gender and mental disorder: to examine, for instance, the over-representation of women in present day patient populations and to see how far it 
remains once the data are disaggregated; to explore the extent to which gender is embedded in concepts of mental disorder; and to consider the extent to which the biological, psychological and social factors conducive to mental disorder differ between men and women.

It is feminist writers, such as Phyllis Chesler (1972), Barbara Ehrenreich and Deirdre English (1979), Dorothy Smith (Smith and David 1975), Ihsan Al-Issa (1980), Kim Chernin (1983, 1985), Susan Penfold and Gillian Walker (1984), Susie Orbach (1978, 1986), Elaine Showalter (1987), Susan Bordo (1985, 1990) and Jane Ussher (1991), who have largely opened up the terrain of gender and mental disorder to wider debate. Yet, significantly, very few of them are sociologists by training they are psychologists (Chesler, Al-Issa and Ussher), literary scholars (Showalter), philosophers (Bordo), psychiatrists (Penfold), social workers (Walker) and psychotherapists (Orbach). Sociologists have been markedly absent from discussions of the terrain. One notable exception is Walter Gove (Gove 1972; Gove and Tudor 1972). However, his approach was epidemiological (see Chapter 10 for a fuller discussion of his work) and, while not uninfluenced by feminist writing, he was not a feminist. Feminist sociologists have made relatively little contribution to the field, apart from the important work of Dorothy Smith and the occasional, though significant, incursions by writers such as Carol Smart (1976) and Hilary Allen (1986); but the concern of the latter writers has been more with the criminal justice than the mental health system.

My own approach has its foundations both in sociology and in feminism (although my earlier training was in clinical psychology), and I have sought to locate an understanding of gender and mental disorder within a sociologically informed analysis that is sensitive to, and shaped by, feminist concerns. This book is not, however, intended for an exclusively sociological audience. I hope that it will be of interest to sociological colleagues, feminist or otherwise, who are interested in mental disorder; but I have also written it for those whose background is not in sociology - especially for a range of clinicians and practitioners, such as psychologists, psychiatrists and social workers, who have day-to-day contact with people with some mental disturbance. For this reason I have not assumed any great familiarity with sociological literature, feminist or otherwise. For the sociological cognoscenti this may at times mean that I am rehearsing ideas, concepts and arguments that could have been taken for granted. Yet if I detail some of the sociological arguments, this is not only because they are less familiar to those outside the discipline, but also because I think many repay further exploration. 
The strategy I adopt in exploring this territory is both theoretical and empirical. On the one hand, I examine key concepts and theories which have been deployed in an effort to make sense of the field. This theoretical examination involves not only an exploration of the concepts of gender and mental disorder and of theoretical approaches to them, but also an examination of ideas about their interrelation, both those that focus on the impact of gender on the construction of categories of mental disorder, and those that focus on the origins of mental disorder and the way in which gender may make men or women more or less vulnerable to mental disorder as currently defined.

On the other hand, I draw on a range of empirical material in developing my own analysis and arguments. The data I consider are culled from a range of sources: from official statistics on the social distribution of mental disorder, from a diverse range of social surveys and qualitative interviews, from psychiatric textbooks, policy reports, and so forth - a diversity of documentary data that can help us to build up a detailed picture about the interconnections between gender and mental disorder.

In my view good sociology requires attention both to theory and to empirical data and there is a continuing danger of a split within the discipline, with fashionable theorists prone to build their exciting intellectual castles, which attract much of the academic attention, but are too often poorly grounded empirically, usually contain sweeping generalisations and are, at times, rather inaccessible. Against this there are empirical sociologists engaged in the difficult process of data collection, whose own work may be under-theorised, and is frequently dismissed as empiricist. ${ }^{3}$ I have tried, therefore, to bring both theory and data together as far as possible, recognising that such an enterprise is far from easy and that in so doing one is likely to end up satisfying neither sociological camp.

My debts in writing this book are pervasive. A major debt is to feminist scholars over the past two and a half decades who made it impossible for issues of gender to be ignored within disciplines like sociology. In this it has been a tremendous advantage to be in a department of sociology like that at Essex, which has regularly had six or seven women members of the permanent full-time staff, most with varying interests in aspects of gender. Their presence has been an enormous support and inspiration, not least through the routine, fleeting and 
often apparently trivial interactions that make up the daily round of hard-pressed academic life. Indeed, I owe a debt to all members students and staff - of the Department of Sociology at the University of Essex, which has provided a diverse, challenging and stimulating intellectual environment and a friendly and supportive community in which to work. I also owe a particular debt to Mary Girling, Julie Andrews, Brenda Corti, Sue Aylott and Diane Streeting who have all helped me in different ways to complete this work. I would also like to thank Colin Samson and an anonymous referee who have provided helpful comments on draft chapters.

Of course, the demands of Department and University have also frequently been a distraction from this study and the adverse impact of the Government's strategies for saving money has permeated all aspects of University life. The complex balancing act that is necessary in these circumstances to retain any residue of domestic or social life is regrettably invisible to those who see academics as leading protected lives in their ivory towers. Michael, Lindsay and Jeffrey have generally borne my absences from domestic affairs and my commitments to work with commendable tolerance. I would especially like to thank them for their support, as well as that of Delfina Dolza, Diana Gittins; my parents and friends.

JOAN BUSFIELD 